\title{
Protean Presentations of Severe Hypothyroidism: Decompensated Liver Disease as an Unusual Co-presentation
}

\author{
D'Costa RV \& Nagi DK
}

\section{Edna Coates Diabetes \& Endocrine Unit, Pinderfields Hospital}

\section{Introduction:}

We report a 51-year old lady presenting to hospital with a 3 week history of abdominal and peripheral swelling. Mentation was slow and noted to be pale on admission. She also reported feeling cold, lethargic, reduced exercise tolerance and constipation. She had no prior medical problems, no regular medications and working till the day prior to admission in a garden centre. She was an exsmoker, teetotal and there was a family history of hypothyroidism.

\section{Clinical Findings and Progress:}

Physical assessment revealed pallor, tense ascites, generalised oedema, hypothyroid facies, mild jaundice, slow mentation and delayed reflex relaxation. TSH was $>100 \mathrm{mU} / \mathrm{L}$ and $\mathrm{fT} 4<3$ pmols/L. Started on Levothyroxine with improvement in overall clinical status and mentation with titration of dose. Random Cortisol 405 mmols/L. Liver function tests were significantly deranged with a cholestatic picture, and she had a small pericardial effusion on echocardiogram. CT done at the time of admission for ongoing abdominal discomfort showed a cirrhotic liver and large volume of ascites. Ultrasound showed gross ascites, chronic liver disease features, patent portal vein and normal flow with splenic varices. Gastroscopy showed grade 1 varices. Antinuclear and anti-mitochondrial (AMA) antibody tests were positive, with AMA titre $>1 / 640$; highly suggestive of Primary Biliary Cirrhosis. CHILDS score $=B, \mathrm{MELDNa}=16$

Abdominal paracentesis was undertaken and she received a blood transfusion, was started on Spironolactone. Her condition gradually improved and she was discharged, with referral to the Regional Liver Unit for consideration of transplantation.

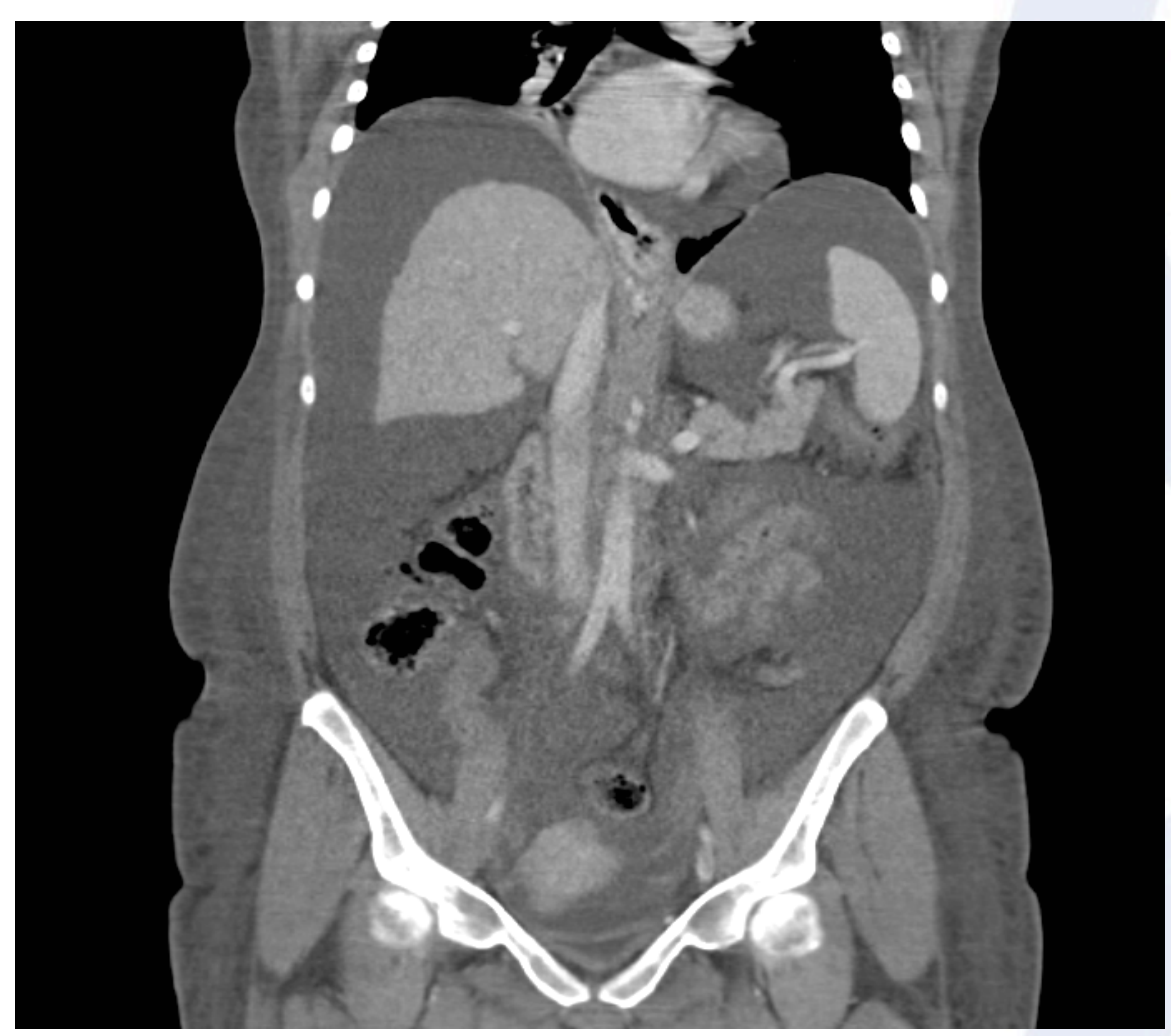

Figure: Abdominal CT: Cirrhotic liver and large volume of ascites.

\section{Results:}

\begin{tabular}{|c|c|c|}
\hline & Result & $\begin{array}{l}\text { Normal range/ } \\
\text { Comments }\end{array}$ \\
\hline TSH & $>100$ & \\
\hline FT4 & $<3$ & \\
\hline Albumin & $30 \mathrm{~g} / \mathrm{L}$ & $35-50$ \\
\hline Alkaline Phosphatase & $1334 \mathrm{U} / \mathrm{L}$ & $30-130$ \\
\hline Alanine Transaminase & $44 \mathrm{U} / \mathrm{L}$ & $0-56$ \\
\hline AST & $52 \mathrm{U} / \mathrm{L}$ & $0-35$ \\
\hline PT & $11.5 \mathrm{~s}$ & $9.5-12.5$ \\
\hline APTT & $32.6 \mathrm{~s}$ & $22-32$ \\
\hline Fibrinogen & $2.3 \mathrm{~g} / \mathrm{L}$ & $1.5-4.5$ \\
\hline Alpha Fetoprotein & $3.3 \mathrm{kU} / \mathrm{L}$ & $0-10$ \\
\hline $\begin{array}{l}\text { Hepatitis } A / B / C \text { and } \\
\text { EBV, CMV serology }\end{array}$ & $\begin{array}{l}\text { Negative for past } \\
\text { infection and nil to } \\
\text { suggest acute } \\
\text { infection }\end{array}$ & \\
\hline \multicolumn{3}{|l|}{$\begin{array}{l}\text { Liver } \\
\text { Autoantibodies }\end{array}$} \\
\hline Antinuclear antibody & $\begin{array}{l}\text { Positive } \\
\text { Speckled pattern ANA } \\
\text { present at titre } 1 / 160\end{array}$ & \\
\hline $\begin{array}{l}\text { Mitochondrial } \\
\text { antibodies }\end{array}$ & $\begin{array}{l}\text { Present } \\
\text { Titre }>1 / 640\end{array}$ & $\begin{array}{l}\text { Highly suggestive of } \\
\text { PBC }\end{array}$ \\
\hline IgAtTG & $16.2 \mathrm{U} / \mathrm{ml}$ & \\
\hline IgA & $7.04 \mathrm{~g} / \mathrm{L}$ & $0.8-4$ \\
\hline IgM & $3.92 \mathrm{~g} / \mathrm{L}$ & $0.5-2$ \\
\hline LKM antibodies & Negative & \\
\hline Ascitic Serology & $\begin{array}{l}\text { No malignant cells } \\
\text { seen }\end{array}$ & \\
\hline Ascitic Culture & Negative & \\
\hline $\begin{array}{l}\text { Gastric Parietal Cell } \\
\text { Antibodies }\end{array}$ & $\begin{array}{l}\text { Not reportable in } \\
\text { presence of } \\
\text { mitochondrial } \\
\text { antibodies }\end{array}$ & \\
\hline
\end{tabular}

\section{Discussion:}

The co-existence of hypothyroidism with other autoimmune conditions is well known. What is unique here is the co-presentation of severe hypothyroidism with established cirrhosis and decompensated liver failure related to Primary Biliary Cirrhosis. While ascites is known to occur in patients with severe hypothyroidism it is important to consider an alternative explanation, particularly if there is no improvement in ascites and liver function with normalisation of thyroid function. 